Case Report

\title{
Recurrent Gastrointestinal Stromal Tumors in the Imatinib Mesylate Era: Treatment Strategies for an Incurable Disease
}

\author{
Rebecca M. Platoff, ${ }^{1}$ William F. Morano, ${ }^{1}$ Luiz Marconcini, ${ }^{2}$ Nicholas DeLeo, ${ }^{1}$ \\ Beth L. Mapow, ${ }^{3}$ Michael Styler, ${ }^{2}$ and Wilbur B. Bowne ${ }^{1}$ \\ ${ }^{1}$ Department of Surgery, Drexel University College of Medicine, Philadelphia, PA, USA \\ ${ }^{2}$ Department of Medicine, Division of Hematology/Oncology, Drexel University College of Medicine, Philadelphia, PA, USA \\ ${ }^{3}$ Department of Pathology and Laboratory Medicine, Drexel University College of Medicine, Philadelphia, PA, USA
}

Correspondence should be addressed to Wilbur B. Bowne; wilbur.bowne@drexelmed.edu

Received 2 June 2017; Accepted 9 October 2017; Published 30 November 2017

Academic Editor: Jaime De la Garza

Copyright $\odot 2017$ Rebecca M. Platoff et al. This is an open access article distributed under the Creative Commons Attribution License, which permits unrestricted use, distribution, and reproduction in any medium, provided the original work is properly cited.

Introduction. Recurrence of gastrointestinal stromal tumors (GISTs) after surgical resection and imatinib mesylate (IM) adjuvant therapy poses a significant treatment challenge. We present the case of a patient who underwent surgical resection after recurrence and review the current literature regarding treatment. Case Presentation. A 58-year-old man with a large intra-abdominal jejunal GIST was treated with complete surgical resection followed by IM. The patient experienced disease recurrence 3.5 years later and underwent IM dose escalation and reresection. Conclusion. Current strategies to treat recurrent GIST include dose escalation, modifying adjuvant tyrosine kinase inhibitor therapy, and surgery. High-level evidence will be required to better define the combinatory roles of tyrosine kinase inhibitor therapy, guided by molecular profiling, and surgery in the management of recurrent GIST.

\section{Introduction}

Although rare, with an estimated incidence of 1.5 cases per 100,000 person years, gastrointestinal stromal tumors (GISTs) are the most common mesenchymal neoplasm of the gastrointestinal tract [1-5]. They arise from the interstitial cells of Cajal and most commonly occur in the stomach (50-60\%), duodenum and small bowel (20-35\%), rectum (5\%), esophagus (2\%), and rarely in the omentum, mesentery, and retroperitoneum $[1,6,7]$.

A breakthrough in the management of GISTs was the development of tyrosine kinase inhibitors (TKIs), most notably imatinib mesylate (IM), which targets a mutation in c-Kit, a gene encoding a tyrosine kinase receptor and found in $80-90 \%$ of patients with GIST $[1,6,8-12]$. Before the development of targeted therapy, greater than $50 \%$ recurred within two years of surgery $[1,6,10,13]$. IM is recommended by the FDA in the adjuvant setting for intermediate/highrisk disease as a result of the Z9001 trial and has been used in the neoadjuvant setting for potentially resectable disease
$[9,14,15]$. DeMatteo et al. demonstrated in this randomized controlled trial that one year of IM improved recurrencefree survival as compared to placebo, regardless of tumor size [9]. In 2012, Joensuu et al. further showed that three years of adjuvant imatinib conferred an overall survival advantage compared with one year of treatment [16]. This therapy has become the mainstay of adjuvant treatment for intermediate/high-risk GISTs [6, 17].

Despite remarkable improvements, management of recurrent disease remains largely undefined, in particular the role of surgical resection in recurrent disease. We present a case of recurrent GIST managed surgically after progression on adjuvant TKI therapy and review the current literature regarding management strategies for recurrent GIST.

\section{Case Report}

A 58-year-old man presented to his primary care physician with vague abdominal pain, constipation, and one year of urinary hesitancy. Abdominopelvic CT scan revealed 


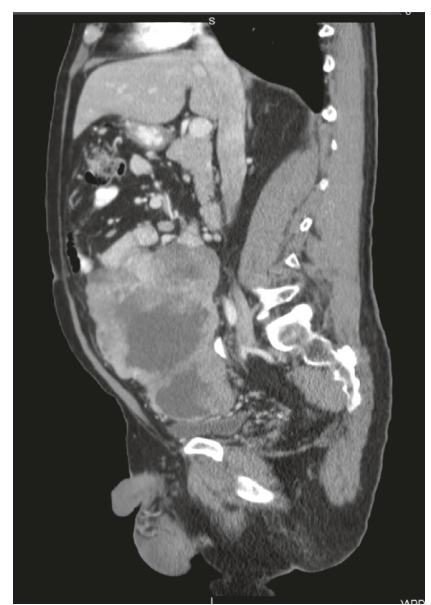

(a)

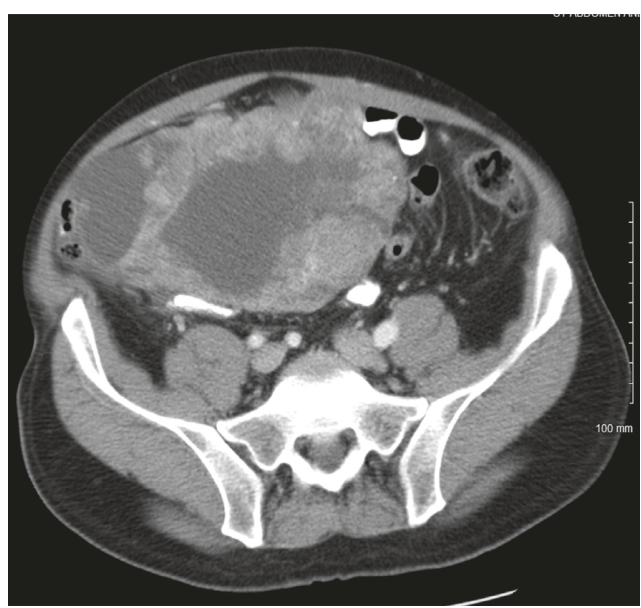

(b)

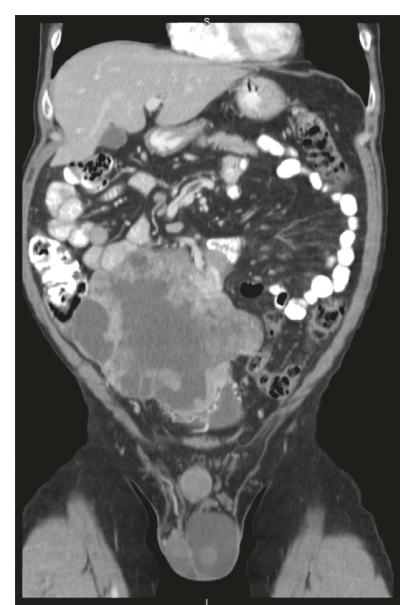

(c)

Figure 1: Sagittal (a), axial (b), and coronal (c) images of CT with IV contrast showing the large, lobulated primary mass that was discovered in January 2013.

a complex, lobulated, enhancing, intraperitoneal mass measuring $18 \times 19 \times 10 \mathrm{~cm}$, extending from the umbilicus to the level of the superior acetabulum (Figure 1). He underwent resection of the mass, including small bowel and partial bladder resection in January 2013. Pathology confirmed complete resection (R0) of high-grade GIST originating from the proximal jejunum, stage IIIB (pT4a, pNx). The tumor was spindle-cell subtype, with the mitotic rate of 8/10 HPF, and necrosis. Immunohistochemistry (IHC) showed membrane positivity for CD117, beta-catenin, vimentin, and smooth muscle actin (SMA). Mutational analysis demonstrated no mutations in the $c$-Kit proto-oncogene or platelet-derived growth factor receptor alpha (PDGFRA). Risk of recurrence was determined to be $90 \%$ [18-23]. He began imatinib mesylate $400 \mathrm{mg}$ daily postoperatively. No evidence of tumor recurrence was detected over three years postoperatively. The patient tolerated imatinib well, except for mild diarrhea (grade 1 CTCAE) [24].

In May 2016, surveillance CT revealed a $3.5 \times 2.8 \mathrm{~cm}$ left lower quadrant mass abutting the sigmoid colon (Figure 2). IM dosage was empirically increased from $400 \mathrm{mg}$ to $800 \mathrm{mg}$ daily, but repeat imaging in July 2016 showed disease progression. The left lower quadrant lesion had grown in size to $4.0 \times 3.3 \times 3.2 \mathrm{~cm}$, with extrinsic compression on the sigmoid colon, with a $2.4 \times 2.1 \times 2.5 \mathrm{~cm}$ periumbilical lesion. Additionally, a new right upper quadrant lesion was noted, approximately $5.3 \times 3.7 \times 2.1 \mathrm{~cm}$. In late July 2016, diagnostic laparoscopy was performed (detecting a right lower quadrant peritoneal nodule), followed by laparotomy, small bowel resection, resection of right upper quadrant lesion, sigmoidectomy, and resection of right lower quadrant peritoneal nodule (Figure 3 ). The pathology revealed highgrade GIST with negative margins and absence of $c$-Kit mutation. Molecular profiling and next-generation sequencing (NGS) of the recurrent disease indicated susceptibility to sunitinib based on the presence of wild-type (WT) $c$-Kit. Accordingly, the patient was switched from imatinib to sunitinib. Follow-up CT in May 2017 showed no signs of tumor recurrence, with patient follow-up at threemonth intervals [14].

\section{Discussion}

In the case of primary GIST, surgery remains the definitive therapy for patients with low- and intermediate-risk disease [25]. For patients with high-risk disease (defined by the $\mathrm{NIH}$ Consensus Criteria as [1] size $>10 \mathrm{~cm}$, [2] mitotic rate $>10 / 50 \mathrm{hpf}$ field or [3] mitotic rate $>5 / 50 \mathrm{hpf}$ and tumor size $>5 \mathrm{~cm}$, or [4] tumor rupture spontaneously or at surgery), adjuvant TKI therapy has been shown to add significant survival benefit $[9,26]$.

The Z9001 Trial revolutionized the treatment of GIST, demonstrating improvement in 1-year recurrence-free survival of $98 \%$ versus $83 \%$ in treatment and placebo groups, respectively [9]. Thereafter, the Scandinavian Sarcoma Group (SSG) trial, comparing 1 and 3 years of imatinib therapy, showed improved 5-year recurrence-free survival of $47.9 \%$ and $65.6 \%$, respectively [16]. Of note, approximately $15 \%$ of GISTs have no detectable $c$-Kit or PDGFRA mutation [27]. The benefit from adjuvant imatinib is minimal in $c$-Kit/PDGFRA-WT patients. Specifically, in the study by Corless et al., imatinib was associated with higher recurrencefree survival versus placebo in patients with $c$-Kit exon 11 deletions but was not significantly associated with PDGFRA mutation or wild-type tumors [28]. Thus, risk of recurrence is higher, and treatment with imatinib is debated [29]. Nevertheless, NCCN recommendations suggest continued use of adjuvant imatinib therapy for these patients.

GIST recurrence in the IM era is largely considered incurable, and treatment strategies are aimed at delaying progression $[6,16]$. Despite response to TKI therapy, many patients with high-risk GIST eventually develop recurrent disease [6]. In the SSG study, $65.6 \%$ of those who completed 3 years of adjuvant imatinib were alive without recurrence 5 years after study entry. However, $34.4 \%$ of those treated experienced recurrence requiring further management [16]. 


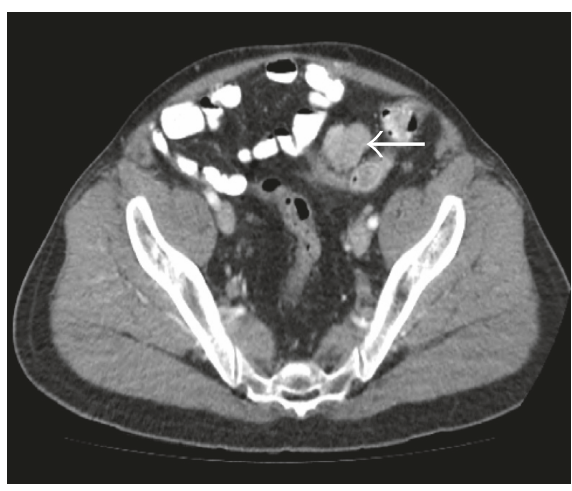

(a)

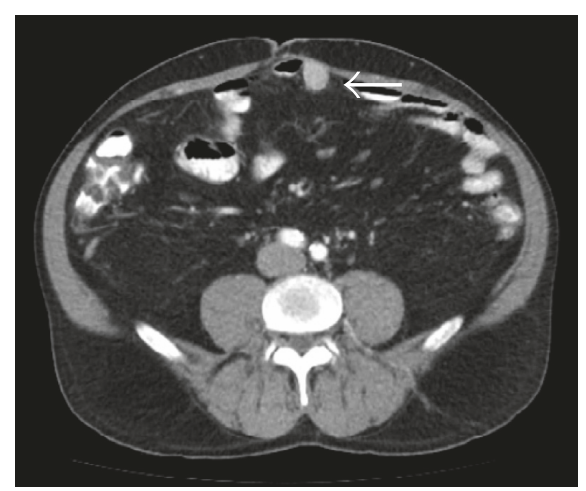

(b)

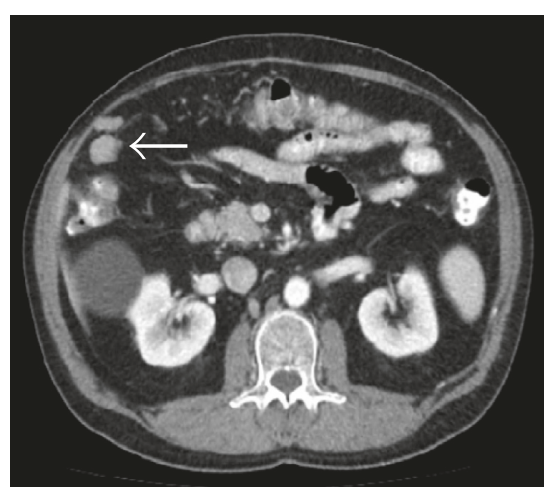

(c)

Figure 2: Axial CT images demonstrating recurrent lesions (white arrows) in the left lower quadrant (a), adherent to the anterior abdominal wall (b), and in the right upper quadrant (c).

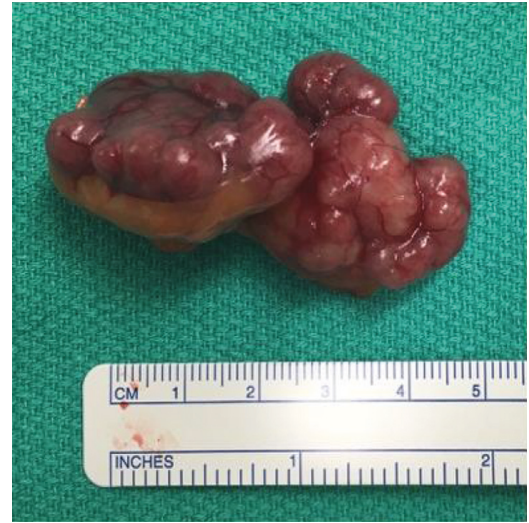

(a)

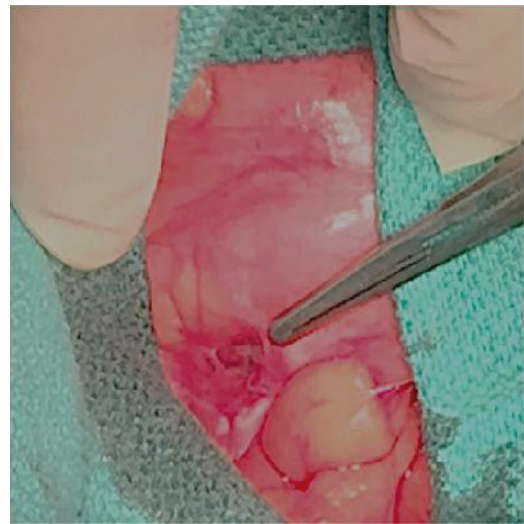

(c)

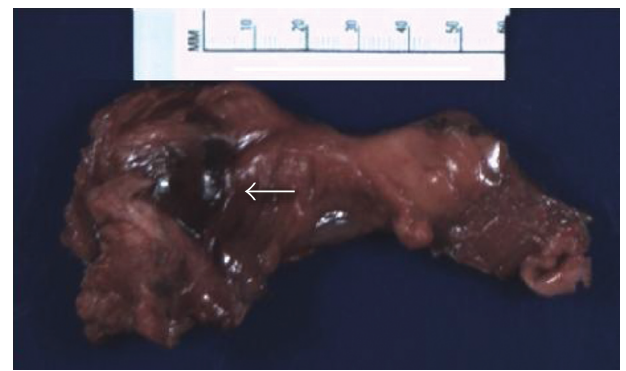

(b)

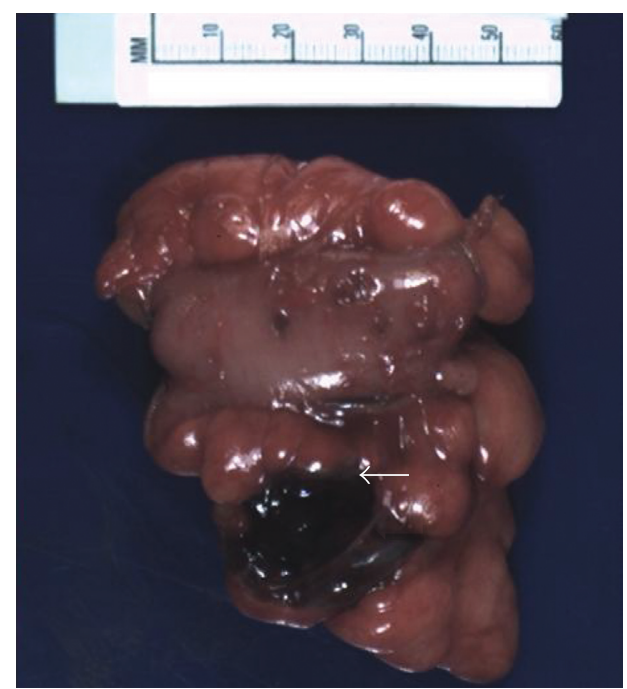

(d)

FIgURE 3: (a) Gross specimen of right upper quadrant recurrent GIST lesion. (b) Anterior abdominal wall mass (white arrow) adherent to the resected loop of the small intestine. (c) Small nodule within the mesentery discovered on diagnostic laparoscopy and resected. (d) Gross specimen demonstrating necrotic sigmoid lesion (white arrow) adherent to resected sigmoid. 
TABLE 1: Institutional studies demonstrating benefit of TKI therapy for recurrent GIST.

\begin{tabular}{|c|c|c|c|c|}
\hline & Study design & Number of patients & Primary endpoint & Main findings \\
\hline $\begin{array}{l}\text { Demetri } \\
\text { et al. [30] }\end{array}$ & $\begin{array}{l}\text { Randomized, double-blind, placebo- } \\
\text { controlled, multicenter, international } \\
\text { trial comparing sunitinib versus placebo } \\
\text { after imatinib failure }\end{array}$ & $\begin{array}{l}321 \text { (207 sunitinib } \\
\text { versus } 105 \text { placebo } \\
\text { patients) }\end{array}$ & Tumor progression & $\begin{array}{c}\text { Median time to tumor progression: } \\
27.3 \text { weeks in patients receiving } \\
\text { sunitinib versus } 6.4 \text { weeks with } \\
\text { placebo }\end{array}$ \\
\hline $\begin{array}{l}\text { MetaGIST } \\
{[31]}\end{array}$ & $\begin{array}{l}\text { Analysis of two large, randomized, } \\
\text { cooperative group studies comparing } \\
\text { two doses of IM ( } 400 \mathrm{mg} \text { daily versus } \\
\text { twice daily) in } 1640 \text { patients with } \\
\text { advanced GISTs }\end{array}$ & $\begin{array}{l}1640 \text { (data analysis } \\
\text { after } 344 \text { and } 321 \\
\text { cases of progression } \\
\text { or death in each } \\
\text { study) }\end{array}$ & PFS and OS & $\begin{array}{l}\text { High-dose imatinib } 800 \mathrm{mg} \text { daily } \\
\text { improved PFS but not OS compared } \\
\text { to imatinib } 400 \mathrm{mg} \text { daily }\end{array}$ \\
\hline $\begin{array}{l}\text { Reichardt } \\
\text { et al. [32] }\end{array}$ & $\begin{array}{l}\text { Randomized phase III open-label trial } \\
\text { comparing nilotinib versus best } \\
\text { supportive care with advanced GIST } \\
\text { following prior imatinib/sunitinib failure }\end{array}$ & $\begin{array}{l}\quad 248(2: 1 \\
\text { randomization } \\
\text { nilotinib or best } \\
\text { supportive care })\end{array}$ & PFS, OS & $\begin{array}{c}\text { Subset analysis of patients with one } \\
\text { prior regimen each of imatinib and } \\
\text { sunitinib showed significant increase } \\
\text { in median OS in favor of nilotinib } \\
\text { versus best supportive care }\end{array}$ \\
\hline $\begin{array}{l}\text { Demetri } \\
\text { et al. [33] }\end{array}$ & $\begin{array}{l}\text { Randomized, double-blinded, placebo- } \\
\text { controlled, multicenter, international } \\
\text { trial comparing regorafenib versus } \\
\text { placebo after imatinib/sunitinib failure }\end{array}$ & $\begin{array}{l}199 \text { (133 regorafenib } \\
\text { versus } 66 \text { placebo } \\
\text { patients) }\end{array}$ & PFS & $\begin{array}{l}\text { Median PFS } 4.8 \text { months for } \\
\text { regorafenib versus } 0.9 \text { months for } \\
\text { placebo }\end{array}$ \\
\hline $\begin{array}{l}\text { Seifert } \\
\text { et al. [34] }\end{array}$ & $\begin{array}{l}\text { Analysis of } 85 \text { patients with GISTs to } \\
\text { determine expression of immune } \\
\text { checkpoint molecules and effects of } \\
\text { combination IM + PD-1/PD-L1 } \\
\text { blockade in murine GISTs }\end{array}$ & $\begin{array}{l}85 \text { (blood samples } \\
\text { from patients with } \\
\text { GISTs) }\end{array}$ & $\begin{array}{l}\text { PD-1 receptor } \\
\text { expression in T-cells } \\
\text { of human GISTs } \\
\text { T-cell function in } \\
\text { mice with GISTs } \\
\text { treated with IM and } \\
\text { PD-1/PD-L1 } \\
\text { inhibitor }\end{array}$ & $\begin{array}{l}\text { The PD-1 inhibitory receptors were } \\
\text { upregulated on tumor-infiltrating T- } \\
\text { cells compared with T-cells from } \\
\text { matched blood } \\
\text { PD-1 expression on T-cells was } \\
\text { highest in IM-treated human GISTs } \\
\text { PD-1/PD-L1 blockade in vivo had no } \\
\text { efficacy alone but enhanced } \\
\text { antitumor effects of IM by increasing } \\
\text { T-cell effector function }\end{array}$ \\
\hline
\end{tabular}

$\mathrm{IM}=$ imatinib mesylate, $\mathrm{PFS}=$ progression - free survival, $\mathrm{OS}=$ overall survival.

Table 1 highlights current institutional studies demonstrating benefit of TKI therapy for recurrent GIST. Treatment options are to initially escalate TKI dose or switch to a second-line drug, typically sunitinib malate $[6,13]$. Imatinib can be increased from $400 \mathrm{mg}$ to $800 \mathrm{mg}$ daily, with an approximate $30 \%$ response rate in patients with KIT exon 9 mutations and acceptable toxicity profile [6, 31]. While c-Kit exon 11 mutations tend to have a higher response to imatinib, primary resistance in the first 6 months of treatment can occur with $c$-Kit exon 9, exon 18, and PDGFRA mutations [35-37]. Secondary resistance after six months can be observed with acquisition of new KIT kinase mutations such as in $c$-Kit exon 17 or $c$-Kit kinase domain 1 [38-40].

Sunitinib targets $c$-Kit and PDGFR-alpha and -beta receptors, among others [6]. In our patient, after resection of recurrence, NGS demonstrated a WT $c$-Kit, signaling potential benefit with sunitinib. Clinical benefit (partial response or stable disease for greater than or equal to 6 months) with sunitinib was observed with progression-free and overall survival in imatinib-resistant GIST [41]. In patients with WT $c$-Kit, Heinrich et al. showed a median progression-free survival of 19 months for patients treated with sunitinib after progression on imatinib versus 5.1 months for those with exon 11 mutations $(p=0.03)$ [41]. Similarly, a study by Demetri et al. showed improved median time to tumor progression for sunitinib versus placebo of approximately
27 weeks versus 6 weeks [30]. Subsequent progression from second-line therapy can then be treated with regorafenib, an oral multikinase inhibitor with increased progression-free survival but not overall survival compared to placebo [33].

A key principle in treatment of recurrent and/or metastatic GIST is to continue imatinib or second-line therapy indefinitely, as it has been shown that patients who discontinue therapy have higher rates of disease progression [6]. Moreover, recent studies have found strong linear correlations between survival time and duration of TKI therapy after diagnosis of recurrence/metastasis $[1,13$, 26, 42]. NGS of the 592 genes most commonly associated with cancer, should expand our understanding of clonal evolution and pathogenesis of disease (high-risk primary and recurrence).

Another avenue in the early phase of exploration is treatment with immunotherapy. Seifert et al. analyzed 85 patients with GIST to determine expression of immune checkpoint molecules and the effects of combination imatinib and PD-1/PD-L1 blockade in KitV558 $\Delta /+$ mice that develop GIST. The PD-1 inhibitory receptors were upregulated on tumor-infiltrating T-cells as compared to T-cells from matched blood. PD-1 and PD-L1 blockade in vivo had no efficacy alone but enhanced the antitumor effects of imatinib by increasing T-cell effector function [34].

In addition to TKIs, surgery remains an important consideration in the management of recurrent GIST (Table 2). 
TABLE 2: Institutional studies demonstrating benefit of surgery for recurrent GIST.

\begin{tabular}{|c|c|c|c|c|c|}
\hline & Study design & Number of patients & $\begin{array}{l}\text { Primary } \\
\text { endpoint }\end{array}$ & $\mathrm{R} 0$ resection & Main findings \\
\hline $\begin{array}{l}\text { Bischof } \\
\text { et al. [1] }\end{array}$ & $\begin{array}{l}\text { Multi-institutional } \\
\text { retrospective cohort }\end{array}$ & $\begin{array}{l}158 \text { (87 locally advanced, } \\
71 \text { recurrent/metastatic) }\end{array}$ & RFS, OS & $\begin{array}{c}69 \% \text { (recurrent/ } \\
\text { metastatic) versus } \\
87.4 \% \text { (locally } \\
\text { advanced) } \\
\end{array}$ & $\begin{array}{c}\text { TKI-sensitive } \\
\text { recurrent/metastatic } \\
\text { disease-improved RFS, OS after } \\
\text { surgery }\end{array}$ \\
\hline $\begin{array}{l}\text { Du et al. } \\
{[43]}\end{array}$ & $\begin{array}{c}\text { Phase III multicenter trial for } \\
\text { recurrent/metastatic on IM } \\
+/- \text { surgery for residual } \\
\text { disease }\end{array}$ & $\begin{array}{l}41 \text { (19 IM + surgery, } \\
22 \text { IM alone) }\end{array}$ & PFS & $73.6 \%$ & $\begin{array}{c}\text { Trend towards improved PFS in } \\
\text { surgery group }\end{array}$ \\
\hline $\begin{array}{l}\text { Tan et al. } \\
{[13]}\end{array}$ & $\begin{array}{c}\text { Retrospective } \\
\text { cohort-upfront surgery } \\
\text { versus TKI for recurrence }\end{array}$ & $\begin{array}{l}186 \text { (56 recurrent-30 } \\
\text { resectable, } 24 \text { underwent } \\
\text { surgery for recurrence) }\end{array}$ & DFS, OS & $\begin{array}{l}75 \%(18 \text { of } 24) \text { in } \\
\text { upfront surgery } \\
\text { group }\end{array}$ & $\begin{array}{l}\text { Improved OS and DFS with } \\
\text { surgery }\end{array}$ \\
\hline $\begin{array}{l}\text { Chang } \\
\text { et al. [17] }\end{array}$ & $\begin{array}{c}\text { Prospectively collected } \\
\text { retrospective } \\
\text { review-imatinib + surgery } \\
\text { (early versus late groups) } \\
\text { versus IM only }\end{array}$ & $\begin{array}{c}182 \text { (89 metastatic, } \\
93 \text { recurrent, } \\
76 \text { underwent surgery) }\end{array}$ & $\begin{array}{l}\text { Clinical } \\
\text { response, } \\
\text { PFS, OS }\end{array}$ & $\begin{array}{c}31.5 \% \text { (early } \\
\text { surgery) versus } \\
59.1 \% \\
\text { (late surgery) }\end{array}$ & $\begin{array}{l}\text { Improved CR, PR, PFS, OS in early } \\
\text { surgery group; improved CR, PR, } \\
\text { OS in late surgery group }\end{array}$ \\
\hline $\begin{array}{l}\text { Sato et al. } \\
{[25]}\end{array}$ & $\begin{array}{l}\text { Retrospective cohort } \\
\text { comparing IM + surgery to } \\
\text { surgery only }\end{array}$ & $\begin{array}{c}737 \text { (93 recurrent/ } \\
\text { metastatic-50 surgery } \\
\text { + TKI therapy, } 43 \text { TKI } \\
\text { therapy alone) }\end{array}$ & DFI, OS & $58 \%(29$ of 50$)$ & $\begin{array}{l}\text { Improved survival from surgery } \\
+ \text { TKI after complete resection, } \\
\text { response to TKI, }<4 \text { metastatic } \\
\text { lesions, lesions }<100 \mathrm{~mm} \text { total }\end{array}$ \\
\hline
\end{tabular}

$\mathrm{TKI}=$ tyrosine kinase inhibitor, $\mathrm{IM}=$ imatinib mesylate, $\mathrm{OS}=$ overall survival, $\mathrm{DFS}=$ disease-free survival, $\mathrm{PFS}=$ progression-free survival, $\mathrm{CR}=\mathrm{complete}$ response, $\mathrm{PR}=$ partial response, $\mathrm{RFS}=$ recurrence-free survival, $\mathrm{DFI}=$ disease-free interval .

GISTs may follow disease-specific patterns that make recurrence amenable to resection [10,42]. To demonstrate the benefit of surgery itself, studies have focused on its role in GIST recurrence regardless of patients' TKI use. A 2015 retrospective review of 186 patients showed that surgery for resectable, recurrent GIST was associated with increased overall survival compared to patients with resectable disease on TKI therapy alone [13]. In this study, 56 patients experienced recurrence, 30 with resectable disease. Twenty-four of those patients underwent upfront surgery (of which 18 received imatinib postoperatively) and 6 opted for nonoperative management. Their results showed a 1-year survival of $100 \%$ for those who underwent surgery compared to $50 \%$ with medical management alone, with 3 -year survival rates of $80 \%$ versus $50 \%(p=0.04)$, respectively. While surgery alone improved survival over TKI therapy only, their data also demonstrated a median diseasefree survival of 2.9 years for patients who underwent surgery while on imatinib, as compared to 1.4 years after surgery alone. This study established the benefit of upfront surgery for GIST recurrence regardless of response to adjuvant TKI therapy, while also highlighting the combinatory effect of these two treatment strategies. The authors suggest that in patients with resectable, recurrent disease, complete resection of recurrent GIST may eliminate possible mutant strains, avoiding the need for escalation of TKI dosage [13, 15].

Further studies into surgical management of recurrent GIST have shown optimal recurrence-free and overall survival if patients are responding to TKI therapy at the time of surgery. Winer and Raut recommend that imatinib therapy commence prior to surgery, and surgeons should wait a minimum of six months before proceeding with resection [6]. Furthermore, retrospective reviews from the
Istituto Nazionale dei Tumori, Memorial Sloan Kettering Cancer Center, and Brigham and Women's Hospital/DanaFarber Cancer Center demonstrated that these patients benefit most when disease progression has stabilized on imatinib, or less commonly on sunitinib [44-46]. Similarly, Chang et al. showed that timing of surgery relative to TKI therapy may contribute to outcome in a review of $182 \mathrm{pa}-$ tients with advanced/recurrent GIST [17]. In this study, 76 patients undergoing cytoreductive surgery were divided into an "early" group (prior to imatinib use, $n=54$ ) and a "late" group (after imatinib use, $n=22$ ). Those in the late surgery group had a higher rate of R0 resection (59.1\% versus $31.6 \%$, $p=0.02)$, higher complete and partial response rates $(100 \%$ versus $79.6 \%, p=0.02)$, and improved trend in overall survival. The authors imply that as surgery reduces tumor burden, this may delay time to development of secondary resistance, and offers a survival benefit when imatinib therapy is initiated prior to surgery [17].

The quality of resection for GIST recurrence has been found to play a pivotal role in survival [6,25]. A 2016 study by Sato et al., analyzing data from forty Japanese institutions, showed that overall survival is significantly improved with $\mathrm{R} 0 / \mathrm{R} 1$ resection [25]. Of the 93 included patients who experienced recurrence, 50 underwent surgery. Those with R0/R1 resection $(n=34)$ had significantly higher 5 -year overall survival as compared to R2 resection $(n=13)(82.2 \%$ versus $47.0 \%, p=0.018$ ). Notably, the authors found a survival benefit from curative resection but reduced 5-year overall survival for $\mathrm{R} 2$ resection as compared to TKI therapy only ( $47 \%$ versus $60.2 \%)$. Their study concluded that surgical intervention should be reserved only for patients with possibility of achieving R0/R1 resection, 6-12 months after initiation of imatinib therapy. Importantly, R0/R1 
resection of residual disease had a benefit when the number of metastatic lesions was less than 4 , total tumor size was less than $100 \mathrm{~cm}$, and disease remained stable or responsive to TKI therapy [25].

Laparoscopy has become an important consideration in the management of primary GISTs, both for diagnostic and therapeutic purposes, yet literature is sparse regarding its contribution for recurrence. Currently, NCCN guidelines support the use of a laparoscopic approach for resection of GIST in anatomically favorable locations (anterior wall of the stomach, ileum, and jejunum), while also noting that its use may expand after further studies due to the decreased short-term morbidity of this approach [14]. Likewise, diagnostic laparoscopy may be a valuable adjunct when approaching these patients with recurrent or metastatic disease to determine resectability or detect lesions not visualized on imaging.

CT remains the imaging modality of choice for surveillance and selection of patients with recurrence that may be candidates for surgical resection. This allows for monitoring disease progression via a change in size, development of new lesions, or alteration in density on CT demonstrating a response to TKI therapy. Tumor treatment-response, or lack thereof, will help guide whether surgical resection of recurrent disease is appropriate [47]. However, in our patient, laparoscopy allowed for detection of a subradiographic lesion not previously visualized on CT, facilitating complete resection in this patient with highgrade, recurrent GIST.

Paucity of high-level evidence investigating the management of recurrent GIST calls for prospective, randomized controlled studies to evaluate the benefit of surgery compared with TKI therapy alone. The difficulty with conducting such trials is elaborated by $\mathrm{Du}$ et al. who explain that in their experience, both patients and surgeons are resistant to the idea that a computer algorithm is the decision maker for randomizing an intervention as major as surgery. Their prospective, randomized trial comparing surgery and IM therapy for recurrent/metastatic GIST enrolled 41 patients, far short of the planned 210. This study investigated only patients with recurrence and continued response to IM and showed that median overall survival was prolonged in patients who underwent surgery. While their findings were encouraging, they lacked statistical significance due to poor patient accrual [43].

\section{Conclusion}

Recent literature demonstrates a survival benefit with surgical intervention in patients with recurrent GISTs. Factors that may improve survival after surgical management of recurrent GIST include quality of resection, limited burden of disease, and response to TKI therapy. If recurrence develops while on TKI therapy, progression-free survival may be improved with dose escalation or nextgeneration TKIs. Further studies are now needed to elucidate the relative importance of these factors, particularly their impact on patient survival, such as ours, who progressed on TKI therapy, but otherwise had resectable disease with few metastases and optimal performance status. Current literature offers insight into the role of surgery for improving survival in patients with recurrent GIST, with the most significant deficit being whether surgery can provide survival benefit to patients no longer responding to TKI therapy. Clearly, the roles of TKIs and surgery for improving survival in patients with recurrent GIST are not mutually exclusive. Prospective, randomized trials will be required to develop treatment algorithms to delineate combinatory roles of TKIs, guided by molecular profiling, and surgery in the management of recurrent GIST.

\section{Consent}

Written informed consent was obtained from the patient for publication of this case report and any accompanying image.

\section{Conflicts of Interest}

The authors have no financial conflicts to disclose.

\section{Authors' Contributions}

Rebecca M. Platoff and William F. Morano contributed equally to the production of this manuscript.

\section{References}

[1] D. A. Bischof, Y. Kim, I. Blazer et al., "Surgical management of advanced gastrointestinal stromal tumors: an international multi-institutional analysis of 158 patients," Journal of the American College of Surgeons, vol. 219, no. 3, pp. 439-449, 2014.

[2] P. G. Casali, L. Jost, P. Reichardt, M. Schlemmer, J.-Y. Blay, and ESMO Guidelines Working Group, "Gastrointestinal stromal tumors: ESMO clinical recommendations for diagnosis, treatment and follow-up," Annals of Oncology, vol. 19, no. 2, pp. ii35-ii38, 2008.

[3] M. Miettinen and J. Lasota, "Gastrointestinal stromal tumors-definition, clinical, histological, immunohistochemical, and molecular genetic features and differential diagnosis," Virchows Archiv, vol. 438, no. 1, pp. 1-12, 2001.

[4] B. Nilsson, P. Bümming, J. M. Meis-Kindblom et al., "Gastrointestinal stromal tumors: the incidence, prevalence, clinical course, and prognostication in the preimatinib mesylate era," Cancer, vol. 103, no. 4, pp. 821-829, 2005.

[5] G. Tryggvason, H. G. Gíslason, M. K. Magnússon, and J. G. Jónasson, "Gastrointestinal stromal tumors in Iceland, 1990-2003: the Icelandic GIST study, a population-based incidence and pathologic risk stratification study," International Journal of Cancer, vol. 117, no. 2, pp. 289-293, 2005.

[6] J. H. Winer and C. P. Raut, "Management of recurrent gastrointestinal stromal tumors," Journal of Surgical Oncology, vol. 104, no. 8, pp. 915-920, 2011.

[7] C. E. Woodall III, G. N. Brock, J. Fan et al., "An evaluation of 2537 gastrointestinal stromal tumors for a proposed clinical staging system," Archives of Surgery, vol. 144, no. 7, pp. 670-678, 2009.

[8] C. L. Corless, C. M. Barnett, and M. C. Heinrich, "Gastrointestinal stromal tumours: origin and molecular oncology," Nature Reviews Cancer, vol. 11, no. 12, pp. 865-878, 2011. 
[9] R. P. DeMatteo, K. V. Ballman, C. R. Antonescu et al., "Adjuvant imatinib mesylate after resection of localised, primary gastrointestinal stromal tumour: a randomised, double-blind, placebo-controlled trial," The Lancet, vol. 373, no. 9669, pp. 1097-1104, 2009.

[10] R. P. DeMatteo, J. J. Lewis, D. Leung, S. S. Mudan, J. M. Woodruff, and M. F. Brennan, "Two hundred gastrointestinal stromal tumors: recurrence patterns and prognostic factors for survival," Annals of Surgery, vol. 231, no. 1, pp. 51-58, 2000.

[11] G. D. Demetri, M. von Mehren, C. D. Blanke et al., "Efficacy and safety of imatinib mesylate in advanced gastrointestinal stromal tumors," New England Journal of Medicine, vol. 347, no. 7, pp. 472-480, 2002.

[12] H. Joensuu, P. J. Roberts, M. Sarlomo-Rikala et al., "Effect of the tyrosine kinase inhibitor STI571 in a patient with a metastatic gastrointestinal stromal tumor," New England Journal of Medicine, vol. 344, no. 14, pp. 1052-1056, 2001.

[13] G. H. C. Tan, J. S. M. Wong, R. Quek et al., "Role of upfront surgery for recurrent gastrointestinal stromal tumours," ANZ Journal of Surgery, vol. 86, no. 11, pp. 910-915, 2015.

[14] M. von Mehren, R. L. Randall, R. S. Benjamin et al., "Soft tissue sarcoma, version 2.2016, NCCN clinical practice guidelines in oncology," Journal of the National Comprehensive Cancer Network, vol. 14, no. 6, pp. 758-786, 2016.

[15] B. L. Eisenberg, J. Harris, C. Blanke et al., "Phase II trial of neoadjuvant/adjuvant imatinib mesylate (IM) for advanced primary and metastatic/recurrent operable gastrointestinal stromal tumor (GIST): early results of RTOG 0132/ACRIN 6665," Journal of Surgical Oncology, vol. 99, no. 1, pp. 42-47, 2009.

[16] H. Joensuu, M. Eriksson, K. Sundby Hall et al., "One vs three years of adjuvant imatinib for operable gastrointestinal stromal tumor: a randomized trial," Journal of the American Medical Association, vol. 307, no. 12, pp. 1265-1272, 2012.

[17] S.-C. Chang, C.-H. Liao, S.-Y. Wang et al., "Feasibility and timing of cytoreduction surgery in advanced (metastatic or recurrent) gastrointestinal stromal tumors during the era of imatinib," Medicine, vol. 94, no. 24, p. e1014, 2015.

[18] E. Downs-Kelly, B. P. Rubin, and J. R. Goldblum, "Mesenchymal tumors of the gastrointestinal tract," in Odze and Goldblum's Surgical Pathology of the GI Tract, Liver, Biliary Tract, and Pancreas, R. D. Odze and J. R. Goldblum, Eds., Elsevier: Saunders, Philadelphia, PA, USA, 3rd edition, 2015.

[19] M. Miettinen, M. Furlong, M. Sarlomo-Rikala, A. Burke, L. H. Sobin, and J. Lasota, "Gastrointestinal stromal tumors, intramural leiomyomas, and leiomyosarcomas in the rectum and anus: a clinicopathologic, immunohistochemical, and molecular genetic study of 144 cases," American Journal of Surgical Pathology, vol. 25, no. 9, pp. 1121-1133, 2001.

[20] M. Miettinen, J. Kopczynski, H. R. Makhlouf et al., "Gastrointestinal stromal tumors, intramural leiomyomas, and leiomyosarcomas in the duodenum: a clinicopathologic, immunohistochemical, and molecular genetic study of 167 cases," American Journal of Surgical Pathology, vol. 27, no. 5, pp. 625-641, 2003.

[21] M. Miettinen and J. Lasota, "Gastrointestinal stromal tumors: pathology and prognosis at different sites," Seminars in Diagnostic Pathology, vol. 23, no. 2, pp. 70-83, 2006.

[22] M. Miettinen, H. Makhlouf, L. H. Sobin, and J. Lasota, "Gastrointestinal stromal tumors of the jejunum and ileum: a clinicopathologic, immunohistochemical, and molecular genetic study of 906 cases before imatinib with long-term follow-up," American Journal of Surgical Pathology, vol. 30, no. 4, pp. 477-489, 2006.

[23] M. Miettinen, L. H. Sobin, and J. Lasota, "Gastrointestinal stromal tumors of the stomach: a clinicopathologic, immunohistochemical, and molecular genetic study of 1765 cases with long-term follow-up," American Journal of Surgical Pathology, vol. 29, no. 1, pp. 52-68, 2005.

[24] U.S Dept. of Health and Human Services, "Common Terminology Criteria for Adverse Events (CTCAE) Version 4.0, 2010," April 2017, https://evs.nci.nih.gov/ftp1/CTCAE/ CTCAE_4.03_2010-06-14_QuickReference_8.5x11.pdf.

[25] S. Sato, T. Tsujinaka, T. Masuzawa et al., "Role of metastasectomy for recurrent/metastatic gastrointestinal stromal tumors based on an analysis of the Kinki GIST registry," Surgery Today, vol. 47, no. 1, pp. 58-64, 2017.

[26] H. Joensuu, "Risk stratification of patients diagnosed with gastrointestinal stromal tumor," Human Pathology, vol. 39, no. 10, pp. 1411-1419, 2008.

[27] D. Gasparotto, S. Rossi, M. Polano et al., "Quadruple-negative GIST is a sentinel for unrecognized neurofibromatosis type 1 syndrome," Clinical Cancer Research, vol. 23, no. 1, pp. 273282, 2017.

[28] C. L. Corless, K. V. Ballman, C. R. Antonescu et al., "Pathologic and molecular features correlate with long-term outcome after adjuvant therapy of resected primary GI stromal tumor: the ACOSOG Z9001 trial," Journal of Clinical Oncology, vol. 32, no. 15, pp. 1563-1570, 2014.

[29] H. Joensuu, P. Hohenberger, and C. L. Corless, "Gastrointestinal stromal tumour," The Lancet, vol. 382, no. 9896, pp. 973-983, 2013.

[30] G. D. Demetri, A. T. van Oosterom, C. R. Garrett et al., "Efficacy and safety of sunitinib in patients with advanced gastrointestinal stromal tumour after failure of imatinib: a randomised controlled trial," The Lancet, vol. 368, no. 9544, pp. 1329-1338, 2006.

[31] Gastrointestinal Stromal Tumor Meta-Analysis Group (MetaGIST), "Comparison of two doses of imatinib for the treatment of unresectable or metastatic gastrointestinal stromal tumors: a meta-analysis of 1,640 patients," Journal of Clinical Oncology, vol. 28, no. 7, pp. 1247-1253, 2010.

[32] P. Reichardt, J. Y. Blay, H. Gelderblom et al., "Phase III study of nilotinib versus best supportive care with or without a TKI in patients with gastrointestinal stromal tumors resistant to or intolerant of imatinib and sunitinib," Annals of Oncology, vol. 23, no. 7, pp. 1680-1687, 2012.

[33] G. D. Demetri, P. Reichardt, Y. K. Kang et al., "Efficacy and safety of regorafenib for advanced gastrointestinal stromal tumours after failure of imatinib and sunitinib (GRID): an international, multicentre, randomised, placebo-controlled, phase 3 trial," The Lancet, vol. 381, no. 9863, pp. 295-302, 2013.

[34] A. M. Seifert, S. Zeng, J. Q. Zhang et al., "PD-1/PD-L1 blockade enhances T-cell activity and antitumor efficacy of imatinib in gastrointestinal stromal tumors," Clinical Cancer Research, vol. 23, no. 2, pp. 454-465, 2017.

[35] M. C. Heinrich, C. L. Corless, G. D. Demetri et al., "Kinase mutations and imatinib response in patients with metastatic gastrointestinal stromal tumor," Journal of Clinical Oncology, vol. 21, no. 23, pp. 4342-4349, 2003.

[36] M. C. Heinrich, K. Owzar, C. L. Corless et al., "Correlation of kinase genotype and clinical outcome in the North American Intergroup Phase III Trial of imatinib mesylate for treatment of advanced gastrointestinal stromal tumor: CALGB 150105 study by Cancer and Leukemia Group B and Southwest 
Oncology Group," Journal of Clinical Oncology, vol. 26, no. 33, pp. 5360-5367, 2008.

[37] S. Farag, N. Somaiah, H. Choi et al., "Clinical characteristics and treatment outcome in a large multicenter observational cohort of pdgfra exon 18 mutated gastrointestinal stromal tumor (GIST) patients," European Journal of Cancer, vol. 76, no. 5, pp. 76-83, 2017.

[38] C. R. Antonescu, P. Besmer, T. Guo et al., "Acquired resistance to imatinib in gastrointestinal stromal tumor occurs through secondary gene mutation," Clinical Cancer Research, vol. 11, no. 11, pp. 4182-4190, 2005.

[39] L. L. Chen, J. C. Trent, E. F. Wu et al., "A missense mutation in KIT kinase domain 1 correlates with imatinib resistance in gastrointestinal stromal tumors," Cancer Research, vol. 64, no. 17, pp. 5913-5919, 2004.

[40] M. C. Heinrich, C. L. Corless, C. D. Blanke et al., "Molecular correlates of imatinib resistance in gastrointestinal stromal tumors," Journal of Clinical Oncology, vol. 24, no. 29, pp. 4764-4774, 2006.

[41] M. C. Heinrich, R. G. Maki, C. L. Corless et al., "Primary and secondary kinase genotypes correlate with the biological and clinical activity of sunitinib in imatinib-resistant gastrointestinal stromal tumor," Journal of Clinical Oncology, vol. 26, no. 33, pp. 5352-5359, 2008.

[42] A. P. Conley, A. Guerin, M. Sasane et al., "Treatment patterns, prescribing decision drivers, and predictors of complete response following disease recurrence in gastrointestinal stromal tumor patients: a chart extract-based approach," Journal of Gastrointestinal Cancer, vol. 45, no. 4, pp. 431-440, 2014.

[43] C.-Y. Du, Y. Zhou, C. Song et al., "Is there a role of surgery in patients with recurrent or metastatic gastrointestinal stromal tumours responding to imatinib: a prospective randomised trial in China," European Journal of Cancer, vol. 50, no. 10, pp. 1772-1778, 2014.

[44] C. P. Raut, M. Posner, J. Desai et al., "Surgical management of advanced gastrointestinal stromal tumors after treatment with targeted systemic therapy using kinase inhibitors," Journal of Clinical Oncology, vol. 24, no. 15, pp. 2325-2331, 2006.

[45] R. P. DeMatteo, R. G. Maki, S. Singer, M. Gonen, M. F. Brennan, and C. R. Antonescu, "Results of tyrosine kinase inhibitor therapy followed by surgical resection for metastatic gastrointestinal stromal tumor," Annals of Surgery, vol. 245, no. 3, pp. 347-352, 2007.

[46] A. Gronchi, M. Fiore, F. Miselli et al., "Surgery of residual disease following molecular-targeted therapy with imatinib mesylate in advanced/metastatic GIST," Annals of Surgery, vol. 245, no. 3, pp. 341-346, 2007.

[47] W. B. Bowne, "Imaging strategies to detect recurrent GIST after surgery: controversies, consensus and guidelines," GIST Cancer Journal, vol. 3, no. 1, pp. 10-15, 2016. 


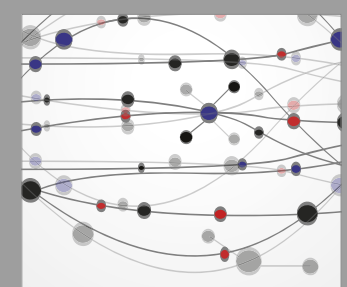

The Scientific World Journal
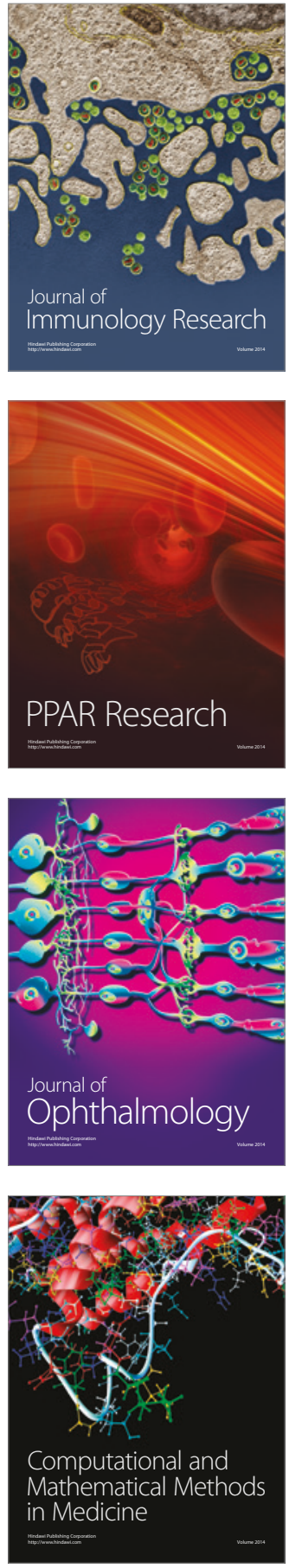

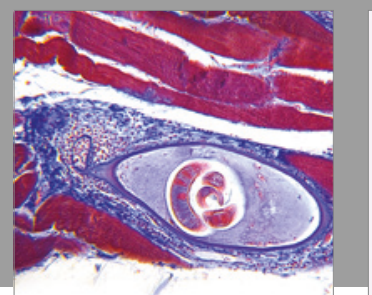

Gastroenterology Research and Practice
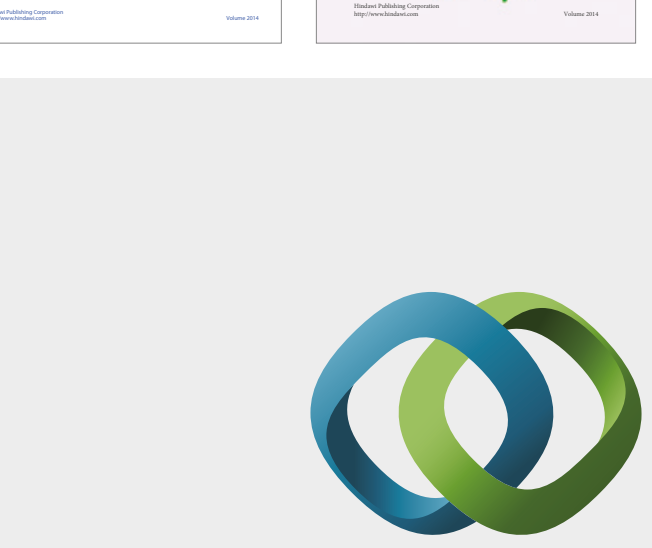

\section{Hindawi}

Submit your manuscripts at

https://www.hindawi.com
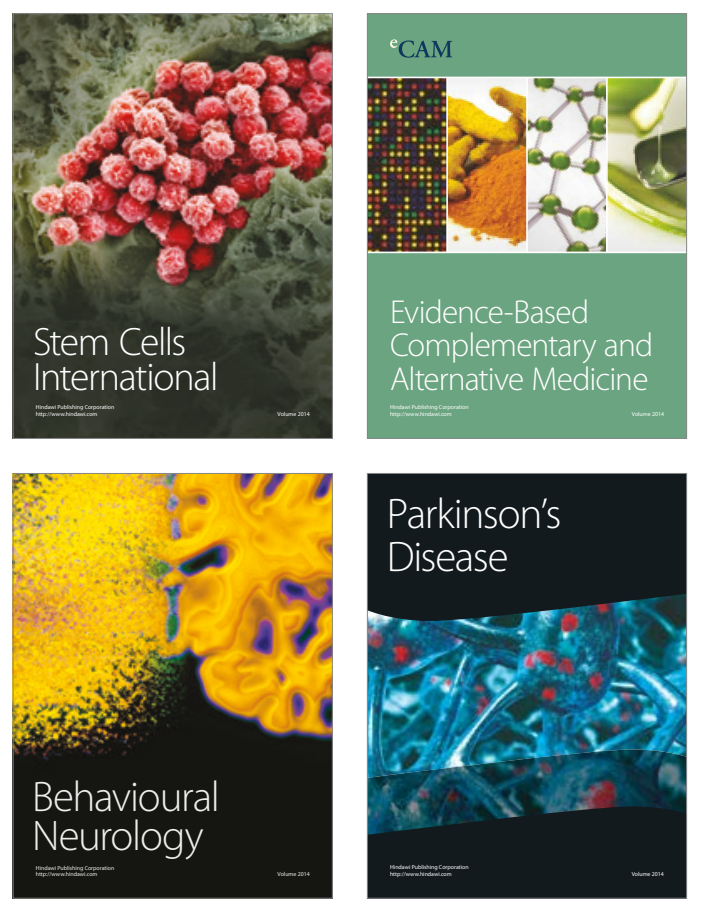
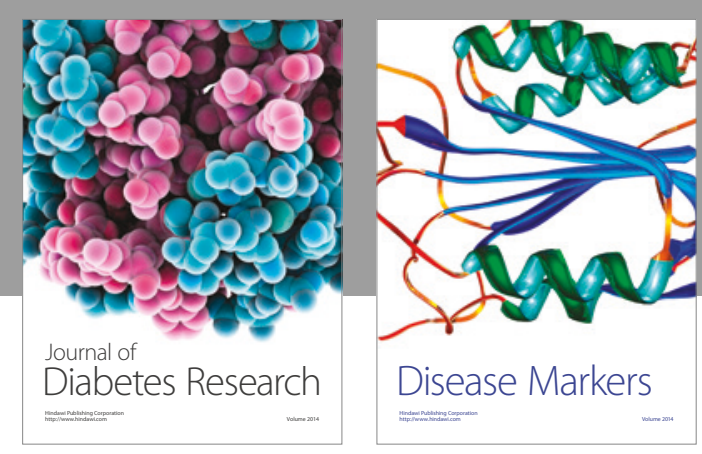

Disease Markers
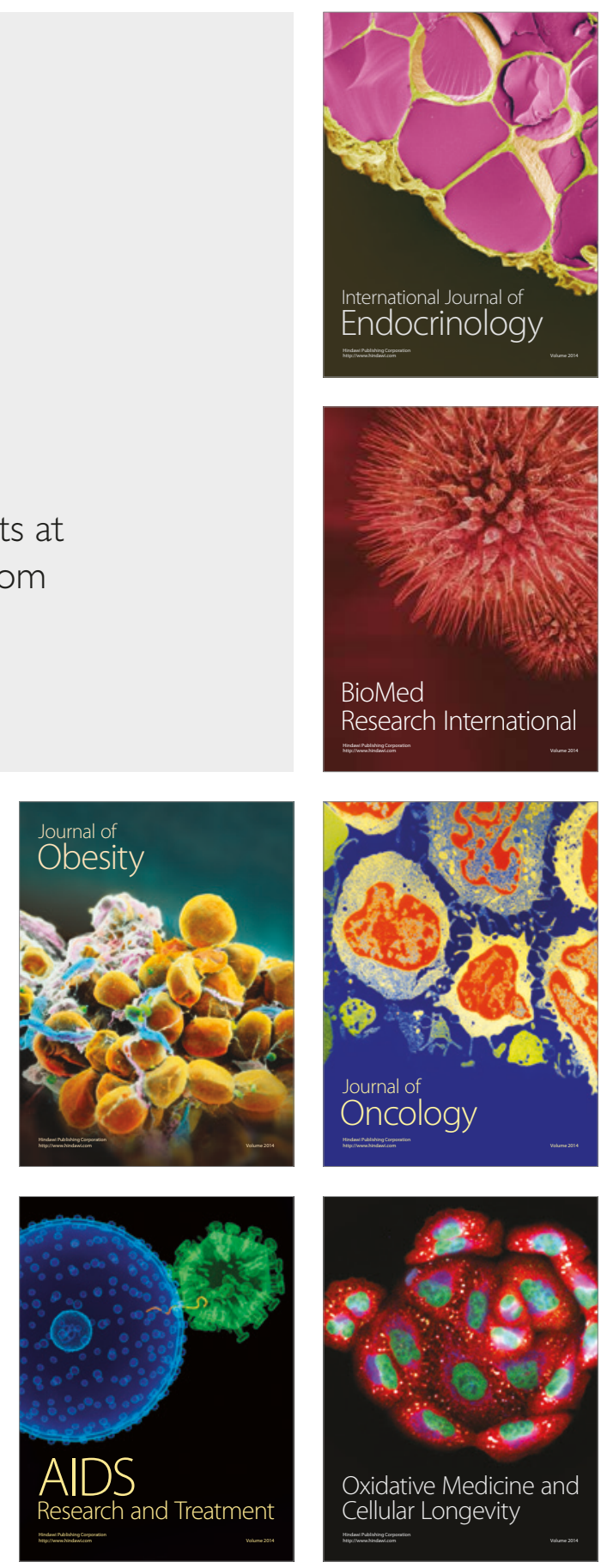